\author{
Witold NIEMIEC ${ }^{1}$ \\ Feliks STACHOWICZ ${ }^{2}$ \\ Tomasz TRZEPIECIŃSKI ${ }^{3}$ \\ Marcin JURGILEWICZ ${ }^{4}$
}

\title{
SANITACJA OBSZARÓW WIEJSKICH POPRZEZ ROLNICZE WYKORZYSTANIE OSADÓW ŚCIEKOWYCH
}

\begin{abstract}
Sanitacja obszarów wiejskich polega na działaniach technicznych, organizacyjnych, ekonomicznych oraz kulturowych, których celem jest podniesienie jakości życia i standardu sanitarnego miejsca zamieszkania. Podstawowymi środkami technicznymi umożliwiającymi sanitację są instalacje do zaopatrzenia w wodę, kanalizacja, składowiska odpadów pochodzenia gospodarczego oraz rolniczego. Rozwój turystyki na terenach wiejskich w Polsce jest zależny przede wszystkim od szybkiego rozwoju infrastruktury kanalizacyjnej oraz przydomowych oczyszczalni ścieków. Przedstawiono podstawowe możliwości przeróbki i wykorzystania osadów z przydomowych oczyszczalni ścieków w gospodarstwach agroturystycznych, a także omówiono główne elementy przydomowych oczyszczalni ścieków takie jak osadnik gnilny, złoża gruntoworoślinne, złoża biologiczne, filtry piaskowe oraz drenaż rozsączający. Jedną z metod utylizacji osadów ściekowych jest ich rolnicze wykorzystanie m.in. do nawożenia plantacji roślin energetycznych. Opracowane urządzenie według wynalazku PL 382062 służy do iniekcyjnego dawkowania nawozów, w szczególności osadów ściekowych. Zaletą urządzenia jest wprowadzanie do gruntu na żądaną głębokość stałych nawozów mineralnych i organicznych z równoczesnym ich przykryciem glebą, co obniża intensywność zapachową i ogranicza utratę lotnych składników nawozowych. Prototyp urządzenia wykonano w ramach współpracy Politechniki Rzeszowskiej oraz SGPRE „Agroenergia” w Boguchwale z R\&D Centre Inventor Sp. z o.o. w Lublinie. Zaprezentowane innowacyjne urządzenie do iniekcyjnego dawkowania nawozów organicznych zapewnia spełnienie wymagań prawnych i agrotechnicznych rolniczego wykorzystania odpadów komunalnych, a także wymogi ustawy o transporcie drogowym.
\end{abstract}

Słowa kluczowe:, oczyszczalnie przydomowe, osadnik gnilny, osady ściekowe, sanitacja, turystyka

\footnotetext{
${ }^{1}$ Autor do korespondencji: Witold Niemiec, Politechnika Rzeszowska, Al. Powstańców Warszawy 12, tel. (17) 8651504, e-mail: wniemiec@ @rz.edu.pl

${ }^{2}$ Feliks Stachowicz, Politechnika Rzeszowska, Al. Powstańców Warszawy 12, tel. (17) 8651538, e-mail: stafel@prz.edu.pl

${ }^{3}$ Tomasz Trzepieciński, Politechnika Rzeszowska, Al. Powstańców Warszawy 12, tel. (17) 8651714, e-mail: tomtrz@prz.edu.pl

${ }^{4}$ Marcin Jurgilewicz, Wyższa Szkoła Informatyki, Zarządzania i Administracji w Warszawie, tel. (22) 6161566, e-mail: b.bukowska@dobrauczelnia.pl
} 


\section{Wprowadzenie}

Według danych Głównego Urzędu Statystycznego w Polsce na koniec 2010 roku z kanalizacji korzystało $62,1 \%$ ogółu ludności (w miastach $86,1 \%$ ludności miast, natomiast na wsi $24,8 \%$ ludności wsi), przy $87,5 \%$ ogółu ludności korzystających z wodociągów sieciowych . Z danych tych wynika, że większość mieszkańców polskich wsi nadal korzysta ze zbiorników bezodpływowych (szamb), które powinny być zastąpione przez przydomowe oczyszczalnie ścieków lub sieć kanalizacyjną. Dynamiczny wzrost instalowanych przydomowych oczyszczalni ścieków spowodowany jest dotacjami z funduszy strukturalnych Unii Europejskiej lub z Narodowego Funduszu Ochrony Środowiska i Gospodarki Wodnej oraz ze środków gminnych.

Sanitacja to program wspólnych działań technicznych, organizacyjnych, ekonomicznych i kulturowych, którego celem jest podniesienie jakości życia, higieny oraz standardu sanitarnego siedliska ludzi [1]. Sanitacja polega więc na odpowiednim rozmieszczeniu i zagospodarowaniu poszczególnych elementów zagrody wiejskiej w sposób zapewniający higieniczne i komfortowe w niej przebywanie. Głównymi środkami technicznymi umożliwiającymi sanitację siedzib są instalacje służące zaopatrzeniu w wodę, kanalizacja, składowiska odpadów pochodzenia bytowo-gospodarczego oraz z produkcji rolniczej [1]. Konieczność sanitacji produkcji żywności jest nieodłącznym elementem życia na obszarach wiejskich. Podstawowym środowiskiem produkcji zdrowej żywności jest wysokiej jakości gleba, a szczególnie jej biologicznie czynna część. Do elementarnych zasad prawidłowej eksploatacji gleby należy zaliczyć m.in. $[2,3]$ :

- uporządkowaną gospodarkę odpadami zwierzęcymi, roślinnymi i socjalnymi,

- optymalizację nawożenia mineralnego i odkwaszania gleb,

- prawidłowe stosowanie środków chemicznych w każdym rodzaju produkcji zwierzęcej i roślinnej,

- racjonalizacja gospodarki biomasą w celach żywieniowych i nawozowych,

- dostosowanie upraw i użytkowania roślin do zanieczyszczenia atmosfery i gleby.

\section{Przydomowe oczyszczalnie ścieków}

Oczyszczalnia przydomowa to zespół urządzeń służących do oczyszczania ścieków bytowych z gospodarstwa domowego, tak by możliwe było ich odprowadzenie już jako oczyszczonych do środowiska (do wód powierzchniowych lub do gruntu) [4]. Instalacje biologiczne pozwalają na odprowadzenie ścieków oczyszczonych bezpośrednio do gruntu lub cieku wodnego, a także ich magazynowanie w celu ponownego użycia na cele gospodarcze. Na terenie wsi pozostaje ponad $11 \mathrm{mln}$ osób nieobsługiwanych przez sieciowe systemy kanaliza- 
cyjne oraz przydomowe oczyszczalnie ścieków. Dysproporcja pomiędzy długością sieci wodociągowej i kanalizacyjnej na obszarach wiejskich może świadczyć o dużej ilości nieoczyszczonych ścieków trafiających w niekontrolowany sposób do gruntu i do wód. Brak zrównoważenia gospodarki wodno-ściekowej stanowi zagrożenie zarówno dla wód powierzchniowych jak i podziemnych.

Jednym z rozwiązań mających na celu zahamowanie nielegalnych zrzutów ścieków nieoczyszczonych do środowiska są przydomowe oczyszczalnie ścieków. Chociaż ilość ścieków odprowadzanych z terenów wiejskich jest stosunkowo niewielka, to wymagają one oczyszczenia w takim samym stopniu jak ścieki z terenów zurbanizowanych [6]. Jakość ścieków odprowadzanych do różnych odbiorników reguluje rozporządzenie Ministra Środowiska z dnia 24 lipca 2006 r. w sprawie warunków jakie należy spełnić przyprowadzaniu ścieków do wód lub do ziemi oraz w sprawie substancji szczególnie szkodliwych dla środowiska wodnego [5]. Jeśli odbiornikiem ścieków oczyszczonych jest grunt lub wody płynące to wymagania jakościowe są następujące [6]:

$-\mathrm{BZT}_{5}<40 \mathrm{mgO}_{2} \cdot \mathrm{dm}^{-3}$,

$-\mathrm{ChZT}_{\mathrm{Cr}}<150 \mathrm{mgO}_{2} \cdot \mathrm{dm}^{-3}$,

- zawiesina ogólna $<50 \mathrm{mg} \cdot \mathrm{dm}^{-3}$.

Wybór sposobu unieszkodliwiania ścieków w przydomowej oczyszczalni ścieków zależy od kilku czynników [6]:

- ilości doprowadzonych ścieków i zawartych w nich zanieczyszczeń,

- warunków gruntowo-wodnych,

- dostępnej powierzchni terenu,

- aspektów ekonomicznych.

\section{Elementy przydomowych oczyszczalni ścieków}

\subsection{Osadnik gnilny}

Osadniki gnilne są wodoszczelnymi zbiornikami jedno- lub wielokomorowymi, które zapewniają wstępną obróbkę ścieków w typowych małych przydomowych oczyszczalniach ścieków. Osadniki podobnie jak szamba są zbiornikami wykonywanymi najczęściej z prefabrykatów betonowych. W ostatnich latach coraz częściej stosuje się gotowe zbiorniki z tworzyw sztucznych. Zadaniem osadnika jest zatrzymanie zawiesin opadających (sedymentujących) oraz zanieczyszczeń pływających (flotujących) (Rys.1). Z cząstek uniesionych na powierzchnię ścieków powstaje kożuch, a cząstki opadłe na dno osadnika tworzą osad, który ulega powolnej fermentacji. W czasie procesu fermentacji cząstki zanieczyszczeń ulegają rozłożeniu na substancje rozpuszczalne i nierozpuszczalne oraz substancje mineralne.

Oferowane w handlu oczyszczalnie ścieków w rzeczywistości są osadnikami gnilnymi, w których ścieki poddawane są fermentacji w warunkach bez- 
tlenowych z użyciem środków chemicznych [7]. W efekcie ścieki nie spełniają norm ścieków oczyszczonych i muszą zostać odprowadzone na dodatkowe oczyszczanie za pomocą drenażu w gruncie.

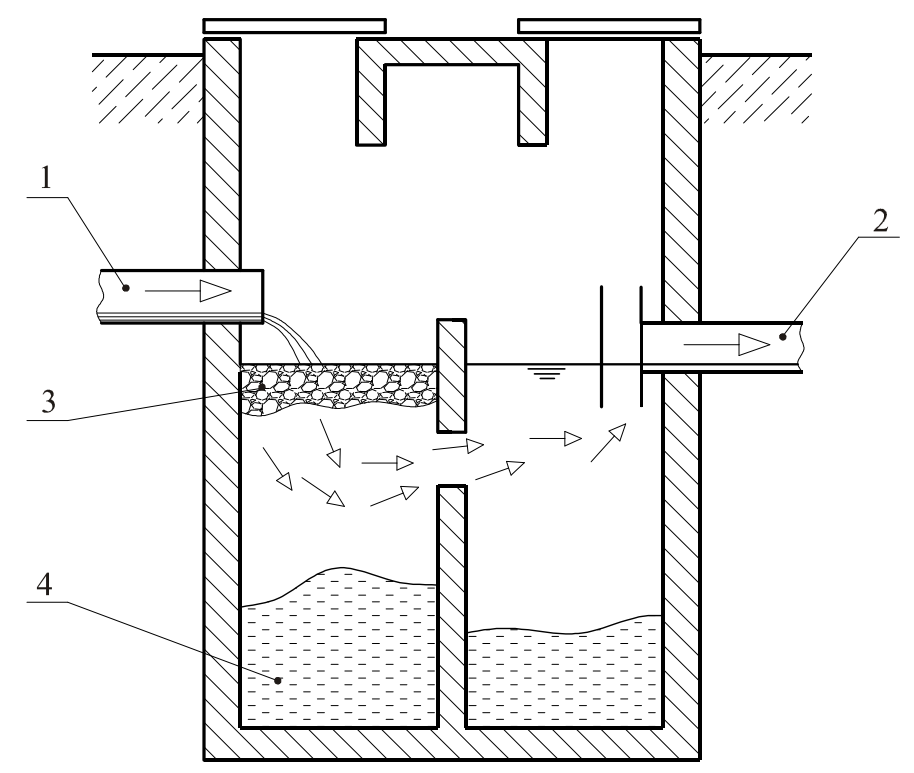

Rys. 1. Osadnik gnilny: 1 - dopływ z instalacji w budynku, 2 - odpływ do biologicznej oczyszczalni ścieków, 3 - części pływające, 4 - osad

Fig. 1. Septic tank; 1 - supply conduit from the installation in the building, 2 - outflow to biological sewage-treatment plant, 3 - float elements, 4 - sludge

Wykonanie drenażu rozsączającego często jest ograniczone warunkami glebowymi (nieprzepuszczalna gleba) oraz wysokim poziom wód gruntowych. Dodatkowo należy liczyć się z wyłączeniem dużej powierzchni terenu z normalnej eksploatacji, a także koniecznością regularnego dosypywania środków biochemicznych do osadnika oraz okresowego wywożenia jego zawartości do zbiorczej oczyszczalni ścieków.

\subsection{Złoża gruntowo-roślinne}

Oczyszczanie w złożach gruntowo-roślinnych wykorzystuje procesy, jakie zachodzą $\mathrm{w}$ warunkach naturalnych na terenach podmokłych oraz bagiennych i polega na redukcji zanieczyszczeń ze ścieków dzięki aktywności biologicznej roślin oraz mikroorganizmów znajdujących się w specjalnie skonstruowanym złożu z wypełnieniem gruntowym (piaskowo-żwirowym) [4]. Oczyszczalnie roślinne można podzielić na systemy z powierzchniowym oraz podpowierzchniowym przepływem ścieków. W pierwszym z systemów poziom ścieków utrzymywany jest ponad powierzchnią gruntu, z kolei rośliny rosną ponad po- 
wierzchnią zwierciadła ścieków. Złoża tego typu składają się z układu do rozlewania ścieków oraz warstwy drenażowej do odprowadzania ścieków. Rośliny są zakorzenione w warstwie mułu, który stanowi znaczną część złoża. W złożach gruntowo-roślinnych z podpowierzchniowym przepływem ścieki przepływają przez warstwę złoża gruntowego lub żwirowego, w której rosną rośliny wspomagające proces oczyszczania. Złoże wyposażone jest w warstwę drenażową rozsączającą i drenaż odbierający ścieki oczyszczone.

Rośliny wykorzystywane w oczyszczalniach gruntowo-roślinnych posiadają tkankę powietrzną, która umożliwia dostarczanie tlenu do znajdujących się pod wodą korzeni. W ten sposób tlen przenika do wierzchniej warstwy złoża i w miarę wzrostu głębokości jego zawartość stopniowo maleje zapewniając występowanie w złożu stref tlenowych i beztlenowych, powodując sprawne usuwanie substancji organicznych oraz związków biogennych [4]. Zanieczyszczenia zawarte w ściekach stają się substancją pokarmową dla drobnoustrojów złoża oraz roślin zielonych, których zadaniem jest dostarczanie tlenu do złoża. Większość zanieczyszczeń zawartych w ściekach jest rozkładana i pochłaniana przez mikroorganizmy żyjące w złożu. Skuteczność usuwania zanieczyszczeń w oczyszczalniach gruntowo-roślinnych sięga [4]:

$-80 \div 90 \%$ zawiesiny i zanieczyszczeń organicznych,

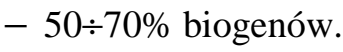

\subsection{Oczyszczalnie z osadem czynnym}

Oczyszczanie ścieków metodą osadu czynnego polega na oczyszczaniu ich w objętości osadu biologicznego zawierającego mikroorganizmy. Podczas procesu oczyszczania w komorze prowadzi się intensywne napowietrzanie i mieszanie prowadząc do szybkiego przyrostu masy mikroorganizmów, które są odprowadzane dalej z oczyszczonymi ściekami do osadnika w celu oddzielenia masy osadu od oczyszczonych ścieków. Nadmiar osadu jest usuwany do unieszkodliwienia lub w przypadku małych oczyszczalni trafia do osadnika gnilnego, gdzie jest poddawany procesowi fermentacji [4]. W porównaniu do innych metod oczyszczania instalacja oczyszczalni z osadem czynnym mieści się zwykle w jednej komorze i nie wymaga dużego terenu pod zabudowę. Zastosowanie odpowiedniej technologii oczyszczania z osadem czynnym umożliwia usuwanie, poza związkami organicznymi, również azotu i fosforu.

\subsection{Złoża biologiczne}

Złoża biologiczne według definicji są to urządzenia techniczne wykorzystujące naturalne zjawisko rozwoju mikroorganizmów na danym podłożu (wypełnieniu) podczas rozkładu związków organicznych [8]. Zasada działania złoża biologicznego opiera się na dopływie zanieczyszczeń, które w trakcie natleniania np. przez ruch obrotowy złoża, (lub dodatkowo zainstalowane aeratory) oraz przez procesy enzymatyczne mikroorganizmów zanieczyszczenia są rozkładane 
i immobilizowane wewnątrz struktury biofilmu [9].W przydomowych oczyszczalniach ścieków najczęściej wykorzystuje się złoża zraszane, w których rozlewane cyklicznie na powierzchni złoża ścieki przepływają przez plastikowe kształtki lub żwir o odpowiedniej granulacji. W warstwie złoża występują obszary napowietrzone oraz strefy o niedoborze tlenu, w których rozwijają się różne gatunki mikroorganizmów żywiących się zanieczyszczeniami organicznymi. Złoża biologiczne stosowane są głównie do usuwania zanieczyszczeń organicznych oraz nitryfikacji związków azotu do azotanów [4]. W zależności od efektywności złoża, odprowadzane ścieki oczyszczone są kierowane bezpośrednio do odbiornika lub mogą być poddane doczyszczaniu na złożu gruntoworoślinnym lub rozsączone w gruncie.

\subsection{Filtry piaskowe}

Idea działania filtra piaskowego polega na biologicznym i fizykochemicznym oczyszczaniu ścieków w złożu żwirowo-piaskowym. Drobne zawiesiny zatrzymywane są na złożu, a materia organiczna rozkładana jest przez mikroorganizmy rozwijające się na materiale złoża. W filtrach piaskowych następuje znaczne usunięcie zawiesiny, materii organicznej oraz również związków azotu i fosforu. Filtry zapewniają skuteczne doczyszczenie ścieków na złożach biologicznych lub złożach roślinnych, przed ich odprowadzeniem do wód powierzchniowych.

Filtry piaskowe dzieli się ze względu na przepływ ścieków na:

- filtry o pionowym przepływie ścieków, w tym filtry pionowe zakryte i filtry pionowe odkryte z jednorazowym i wielokrotnym przepływem ścieków oraz wielokrotnym przepływem ścieków

- filtry o poziomym przepływie ścieków.

$\mathrm{W}$ filtrach piaskowych proces oczyszczania zachodzi wyłącznie w gruncie, a całość złoża może być przekryta gruntem rodzimym (Rys. 2). Grubość warstwy filtracyjnej wynosi $0,6 \div 0,9 \mathrm{~m}$ [4]. Powierzchnia złoża to około $7 \div 8 \mathrm{~m}^{2}$.

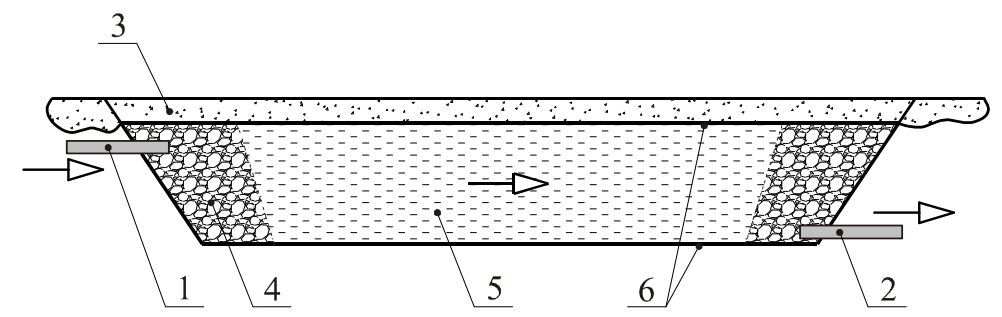

Rys. 2. Filtr piaskowy z poziomym przepływem ścieków: dopływ ścieków z osadnika gnilnego, 2 - odpływ ścieków oczyszczonych, 3 - grunt, 4 - żwir, 5 - złoże piaskowe, 6 - folia (geomembrana)

Fig. 2. Sand filter with horizontal sewage flow: 1 - supply conduit of sewage from the septic tank, 2 - outflow of purifying sewage, 3 - soil, 4 - gravel, 5 - sand filter, 6 - foil (geomembrane) 
Filtry piaskowe stosowane są głównie jako drugi stopień oczyszczania ścieków po osadnikach gnilnych lub osadnikach Imhoffa, jak również jako trzeci stopień po biologicznych procesach oczyszczania, gdy wymagany jest dopływ ustabilizowany i o wysokiej jakości. Ścieki po filtrze piaskowym najczęściej odprowadzane są do wód powierzchniowych, ale mogą być również odprowadzane do gruntu przez studnię chłonną [5].

\subsection{Drenaż rozsączający}

Zadaniem drenażu rozsączającego jest równomierne wprowadzenie do systemu wstępnie oczyszczonych ścieków wypływających z osadnika gnilnego. Drenaż składa się z układu rur rozsączających umieszczonych w rowach wypełnionych specjalnie dobraną warstwą filtracyjną (Rys. 3). Całość przykryta jest warstwą gleby. Odległość dna drenażu od wód gruntowych powinna wynosić minimum $1,5 \mathrm{~m} \mathrm{[4].}$

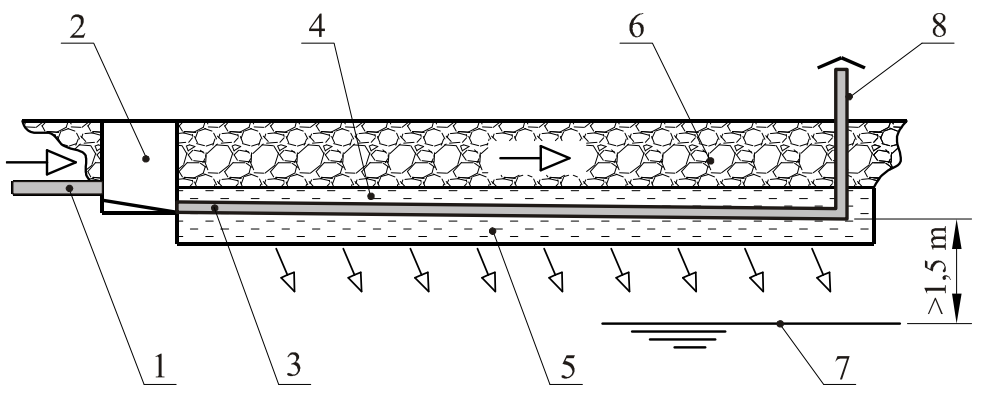

Rys. 3. Drenaż rozsączający: 1 - dopływ ścieków, 2 - studnia rozdzielcza, 3 - przewód rozsączający (drenaż), 4 - warstwa izolacyjna, 5 - warstwa rozsączająca (żwir), 6 - grunt, 7 - poziom wód gruntowych, 8 - wywietrznik

Fig. 3. Infiltrative drainage: supply conduit of sewage, 2 - cubicle well, 3 - infiltrative pipe (drainage), 4 - insulating layer, 5 - infiltrative layer (gravel), 6 - soil, 7 - underground water level, 8 - ventilator

Pod powierzchnią filtracyjną, wytwarza się błona biologiczna będąca wynikiem rozwoju mikroorganizmów, które dokonują rozkładu zanieczyszczeń zawartych w ściekach na substancje stałe i gazowe. Drenaż rozsączający ma ograniczoną zdolność do oczyszczania ścieków, dlatego nie może być stosowany jako samodzielne urządzenie do oczyszczania ścieków. Powinien być wykorzystywany jako końcowy element po osadniku gnilnym i oczyszczalni biologicznej.

\section{Zagospodarowanie osadów ściekowych}

Podczas użytkowania każdej przydomowej oczyszczalni ścieków powstaje osad, który należy zagospodarować. Osad powstaje w osadniku gnilnym w wyniku gromadzenia zawiesiny na dnie zbiornika i pomimo długiego czasu fer- 
mentacji w osadniku zawiera znaczne ilości substancji organicznej oraz mikroorganizmów niebezpiecznych dla zdrowia. Osady ściekowe są poddawane odpowiednim zabiegom technologicznym takim jak wapnowanie, kompostowanie, hydrofitowe odwadnianie, mineralizacja i suszenie, aby spełniały określone normy związane $\mathrm{z}$ ich wykorzystaniem lub składowaniem [10, 11]. Spośród wszystkich sposobów sanitacji i stabilizacji biologicznej kompostowanie masy organicznej jest najprostsze i najtańsze. Osad usuwany jest z osadnika gnilnego z częstotliwością zależną od ilości obsługiwanych mieszkańców i pojemności osadnika - zwykle raz na kilka miesięcy. Zbyt rzadkie usuwanie osadu może doprowadzić do przepełnienia zbiornika i wypływania osadu do części biologicznej oczyszczalni, doprowadzając do jej zniszczenia [4].

Zakaz możliwości składowania osadów ściekowych po 1 stycznia 2013 roku [12] zmusza do poszukiwania nowych sposobów ich zagospodarowania. Jedną z metod utylizacji, wykorzystującą własności nawozowe osadów jest ich przyrodnicze, m.in. rolnicze użytkowanie. Pod pojęciem przyrodniczego użytkowania osadów ściekowych rozumie się stosowanie tych osadów do nawożenia gleb i roślin, rekultywacji gleb zdegradowanych, utrwalania bezglebowych gruntów narażonych na erozyjne działanie wody i wiatru, produkcji kompostu na wyżej wymienione cele oraz do uprawy roślin nieprzeznaczonych do spożycia i do produkcji pasz. Osady ściekowe można także wykorzystać do upraw leśnych i rolniczych w celu produkcji drewna i sadzonek.

Wieloletnie rośliny energetyczne (o różnej budowie oraz różnych systemach korzeniowych) do prawidłowego rozwoju potrzebują odpowiedniej ilości składników pokarmowych, których w wystarczającej ilości na dłuższy okres podczas zakładania plantacji nie można dostarczyć do gleby [13, 14]. Plantacje roślin energetycznych $\mathrm{w}$ trakcie eksploatacji nawożone są powierzchniowo sztucznymi nawozami mineralnymi przy użyciu powszechnie znanych specjalistycznych maszyn zwanych rozrzutnikami nawozów. Efektywność wzbogacania pokarmowego plantacji uzależniona jest od właściwego dawkowania nawozów, głębokości nawożenia oraz bezzwłocznego przykrycia nawozu glebą, czego nie zapewniają klasyczne rozrzutniki nawozów. Proces ten nabiera szczególnego znaczenia $\mathrm{w}$ związku $\mathrm{z}$ wykorzystywaniem do nawożenia odpowiednio przygotowanego osadu komunalnego z oczyszczalni ścieków, którego zastosowanie jest warunkowane bezzwłocznym przykryciem glebą $[15,16]$.

Opracowane urządzenie według wynalazku PL 382062 (rys. 4) [17] służy do iniekcyjnego dawkowania nawozów, w szczególności osadów ściekowych i wchodzi w skład parku maszyn opracowywanych w Politechnice Rzeszowskiej w ramach rozwoju technologii zakładania plantacji oraz zbioru i przetwarzania biomasy [18, 19]. Zaletą urządzenia jest wprowadzanie do gruntu na żądaną głębokość stałych nawozów mineralnych i organicznych o konsystencji sypkiej z równoczesnym ich przykryciem glebą, co obniża intensywność zapachową i ogranicza utratę lotnych składników nawozowych. Nawóz dostarczany 
jest w pobliże masy korzeniowej bez jej uszkodzenia, co ułatwia przyswajanie składników pokarmowych przez rośliny.

Prototyp urządzenia do iniekcyjnego dawkowania do gleby sypkich nawozów organicznych i mineralnych (rys. 4) wykonano w ramach współpracy Politechniki Rzeszowskiej oraz SGPRE „Agroenergia” Boguchwała z R\&D Centre Inventor Sp. z o.o. Lublin.
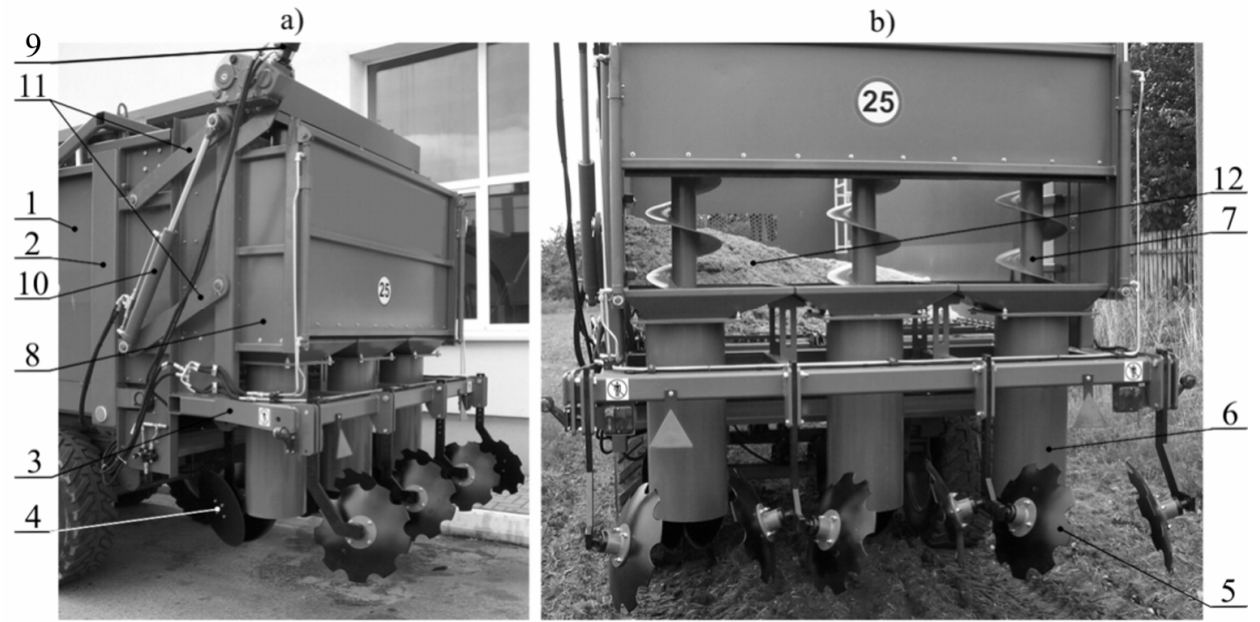

Rys. 4. Prototyp urządzenia do iniekcyjnego dawkowania do gleby sypkich nawozów organicznych i mineralnych wykonany przez R\&D Centre Inventor sp. z o.o. (Lublin) - widok z boku (a) oraz z tyłu (b): 1- rozrzutnik nawozów, 2 - rama nośna, 3 - belka, 4 - krój tarczowy, 5 - obsypnik talerzowy, 6 - cylindryczna obudowa ślimaka, 7 - podajnik ślimakowy, 8 - komora zasypowa, 9 - silnik hydrauliczny, 10 - siłownik hydrauliczny, 11 - ramiona, 12 - nawóz

Fig. 4. Prototype of the device for injection dosage into soil of loose organic and mineral fertilizers built by R\&D Centre Inventor Ltd. (Lublin) - one of the side view (a) and the back view (b): 1 - fertilizer spreader, 2 - base frame, 3 - beam, 4 - disk coulter, 5 - ridging plough, 6 - cylindrical housing of worm, 7 - feeding screw, 8 - loading chamber, 9 - hydraulic engine, 10 - hydraulic cylinder, 11- arms, 12 - fertilizer

Urządzenie mocowane jest do rozrzutnika nawozów 1 i posiada zamocowane do ramy nośnej 2 kroje tarczowe 4, za którymi są usytuowane obsypniki talerzowe 5. Z ramą przystawki sprzężone są cylindryczne obudowy 6 z pracującymi wewnątrz podajnikami ślimakowymi 7. Podajniki ślimakowe posiadają w górnej części, ponad strefą roboczą koła zębate stożkowe odbierające poprzez reduktor napęd z silnika hydraulicznego 9. Każdy z trzech podajników ślimakowych może być alternatywnie indywidualnie wyposażony w silnik hydrauliczny zasilany z układu hydraulicznego ciągnika. Położenie krojów względem belek może być ustalane bezstopniowo poprzez układ hydrauliczny. Do ustawienia urządzenia w pozycję transportową służą ramiona 11 sprzężone z siłownikiem hydraulicznym 10. 
Głębokość rowków do zasypywania nawozem ustalana jest przez zmianę położenia krojów oraz obsypników talerzowych względem podłoża. W czasie pracy masa nawozu w komorze transportowej rozrzutnika jest przesuwana w kierunku przestrzeni zasypowej za pomocą przenośnika podłogowego. Z przestrzeni zasypowej nawóz podawany jest podajnikami ślimakowymi do wykonanych przez kroje rowków w glebie. Wypełnione osadem ściekowym rowki są zasypywane usytuowanymi za krojami talerzowymi obsypnikami.

\section{Podsumowanie}

Podczas oczyszczania ścieków zarówno w przydomowych, jak i zbiorczych oczyszczalniach ścieków powstają osady ściekowe, które mogą stanowić cenny materiał do wykorzystania przyrodniczego i rolniczego. Osady z przydomowych oczyszczalni ścieków są najczęściej transportowane do oczyszczalni zbiorczych, dlatego problem przeróbki i wykorzystania osadów pochodzących z przydomowych oczyszczalni ścieków będzie narastał, powodując problemy eksploatacyjne zbiorczych oczyszczalni ścieków

Jednym ze sposobów zwiększenia areałów roślin energetycznych jest zagospodarowanie wzrastającej ilości gruntów odłogowanych, nieużytków, terenów zdegradowanych lub terenów do tej pory nieeksploatowanych rolniczo, co związane jest z możliwością wykorzystania osadów ściekowych jako nawozu. Osady pochodzące z procesu biologicznego oczyszczania ścieków wymagają stabilizacji i higienizacji. Tak przygotowany osad zastosowany jako nawóz nie stanowi dla gleby zagrożenia bakteriologicznego. Prezentowane innowacyjne urząazenie do iniekcyjnego dawkowania nawozów organicznych zapewnia spełnienie wymagań prawnych i agrotechnicznych rolniczego wykorzystania odpadów komunalnych oraz wymogi ustawy o transporcie drogowym.

\section{Literatura}

[1] Sikorski M.: Stan i zamierzenia w zakresie sanitacji wsi. Wiadomości Melioracyjne i Łąkarskie, tom 38, nr 4, 1995, s. 167-170.

[2] Siuta J., Wasiak G.: zasady wykorzystania osadów ściekowych na cele nieprzemysłowe (przyrodnicze), Inżynieria Ekologiczna, nr 3, 2001, s. 13-42.

[3] Siuta J.: Ochrona powierzchni Ziemi, stan i niezbędne działania, Aura, nr 3, 2000, s. 7-9.

[4] http://www.pkegliwice.pl/pliki/technologie_oczyszczalni.pdf [dostęp: 25 maja 2014 r.].

[5] Rozporządzenie Ministra Środowiska z dnia 24 lipca 2006r. w sprawie warunków jakie należy spełnić przyprowadzaniu ścieków do wód lub do ziemi oraz w sprawie substancji szczególnie szkodliwych dla środowiska wodnego Dz.U. 2006 nr 137 poz. 984.

[6] Chmielowski K., Ślizowski R., Pęgiel K.: Ocena działania przydomowej oczyszczalni ścieków z filtrem piaskowym o przepływie poziomym, Infrastruktura i ekologia obszarów wiejskich, nr 2, 2011, s. 215-223. 
[7] http://www.ekoservis.pl/przydomowe,11,p.html [dostęp: 25 maja 2014 r.].

[8] Kempa E.S.: Oczyszczalnie ścieków na obrotowych złożach tarczowych z samorzutnym napowietrzaniem, Ekotechnika, nr 3, 2001, s. 14-17.

[9] Kania-Surowiec I.: Złoża biologiczne w oczyszczaniu ścieków z recyklingu tworzyw sztucznych, Inżynieria Ekologiczna, nr 32, 2013, s. 74-84.

[10] Szwedziak K.: Charakterystyka osadów ściekowych i rolnicze wykorzystanie, Inżynieria Rolnicza, nr 4, 2006, s. 297-302.

[11] Ślizowski R.: Osady ściekowe, ich stabilizacja i wykorzystanie w rolnictwie, Inżynieria Rolnicza 3, 2002, s. 151-161.

[12] Gromiec M.J., Gromiec T.M.: Podstawy strategii zagospodarowania komunalnych osadów ściekowych w Polsce. W: Kierunki przeróbki i zagospodarowania osadów ściekowych. Red. Z. Heindrich. Wydawnictwo Seidel-Przywecki, Warszawa 2010, s. 7-14.

[13] Niemiec W., Stachowicz F., Szewczyk M., Trzepieciński T.: Technological progress in production, logging and processing of the biomass, SSP - Journal of Civil Engineering, no 2, 2011, s. 85-92.

[14] Niemiec W., Stachowicz F., Szewczyk M., Trzepieciński T.: Production technology and management of energetic plants with lignified shoots. Econtechmod: An International Quaterly Journal on Economics of Technology and Modelling Processes, no 1, 2012, s. 31-34.

[15] Rozporządzenie Ministra Środowiska z dnia 13 lipca 2010 r. w sprawie komunalnych osadów ściekowych. Dz.U. 2010 nr 137 poz. 924.

[16] Ustawa z dnia 14 grudnia 2012 r. o odpadach. Dz.U. 2013 poz. 21.

[17] Niemiec W.: Urządzenie do iniekcyjnego dawkowania do gleby sypkich nawozów organicznych i mineralnych. Politechnika Rzeszowska. Rzeszów. Polska. Opis patentowy, 214031. Zgłosz. P. 382062 z 26.03.2007. Opubl. 29.09.2008.

[18] Niemiec W., Stachowicz F., Szewczyk M., Trzepieciński T.: Technologia wykorzystania biomasy w gospodarstwach małoobszarowych. Zeszyty Naukowe Politechniki Rzeszowskiej. Budownictwo i Inżynieria Środowiska, z. 59, 2012, s. 493-500.

[19] Niemiec W., Stachowicz F., Trzepieciński T.: Rozwój technologii produkcji, zbioru i przetwarzania roślin energetycznych o zdrewniałych pędach, Ekologia i Technika, tom 20, 2012, s. 186-191.

\title{
AGRICULTURAL USAGE OF SEWAGE SLUDGE FOR RURAL SANITATION
}

\author{
S u m m a r y \\ Rural sanitation involves technical, organizational, economic, and cultural actions, which \\ the aim is to improve the quality of life and sanitary standard of a place of residence. The ena- \\ bling sanitation are installations for water supply, sewerage system. Installations for water supply, \\ sewerage system and landfill sites are the basic technical means that enable sanitation. Develop- \\ ment of tourism on rural areas in Poland first of all depends on fast development of sewage sys- \\ tems and small wastewater treatment plants. The basic sources of biotope pollution of a village \\ and the possibility of processing and utilization of sludge from sewage treatment plants are pre-
}


sented. Furthermore, the main elements of the sewage treatment plants such as septic tank, soilplant sludge, biological sludge, sand filters and infiltrative drainage are discussed. One of the methods of utilization of sewage sludge is its agricultural use, among others, to fertilize energy plant plantations. The developed device according to the PL 382062 patent is used to injection dosing of fertilizers, in particular sewage sludge. The main feature is the introduction into the soil to the desired depth of solid mineral and organic fertilizers with their cover of the soil, which reduces the intensity of the odour and also reduces the loss of volatile constituents of the fertilizer. The prototype device was performed in the framework of the Rzeszow University of Technology and SGPRE "Agroenergia" in Boguchwala and R\&D Centre Inventor Ltd in Lublin.

Keywords: household sewage plant, septic tank, sewage sludge, sanitation, tourism

Przestano do redakcji: 22.05.2015 $r$.

Przyjęto do druku: 22.06.2015 r.

DOI:10.7862/rb.2015.61 